\title{
Chinese-English Intercultural Awareness in College English Teaching
}

\author{
Caiyun, Zhang \\ School of Foreign Languages \\ Yan'an University \\ Yan'an, Shaanxi, 716000
}

\begin{abstract}
Intercultural awareness, as an important component of English language communicative competence, plays an important role in cultivating students' English learning interest and intercultural communicative competence, but it is also a link that many teachers and students can easily ignore. In view of this, this paper first analyzes the main problems in college English intercultural awareness teaching, and then discusses the cultivation strategies of college students' English intercultural awareness, aiming to make teachers and students fully aware of the importance of the cultivation of intercultural awareness and improve their English communication skills.
\end{abstract}

Keywords-English teaching; intercultural awareness; cultural teaching; reform stragegy

\section{INTRODUCTION}

Current college English teaching model can only meet students' learning needs in general English. Chinese-English intercultural awareness education is relatively deficient, which affects the improvement of students' intercultural communication ability to a great extent. For example, many college English teachers pay too much attention on the teaching of vocabulary, grammar and other basic knowledge and skills, but rarely involve permeable teaching of western cultures, leading to the separation of college English teaching and western cultures. ${ }^{[1]}$ When students communicate in English, it's easy for them to have cultural conflicts, which may directly result in the failure of interpersonal communication activities. In the context of economic globalization, there are more and more opportunities for college students to communicate in English. To improve students' intercultural communication skills, college English teachers must pay more attention to the cultivation of ChineseEnglish intercultural awareness, and consciously teach western cultural background, life customs, religious beliefs, thinking habits and other knowledge in English teaching process.

\section{THE MAJOR PROBLEMS IN COLLEGE ENGLISH INTERCULTURAL AWARENESS TEACHING}

\section{A. There Is No Clear Intercultural Awareness Teaching Objectives}

Affected by the traditional examination-oriented teaching thinking, the goal of various stages of English teaching in China focuses on basic teaching and improving students' basic application ability. ${ }^{[2]}$ And teaching content mainly includes vocabulary teaching and grammar teaching. The cultivation of students' Chinese-English intercultural awareness is interspersed in various teaching links and does not set clear teaching objectives. This restricts the cultivation of students intercultural awareness and English communicative competence, and makes the English learning of college students mostly stay in the primary stage. Especially in the context of economic globalization, the new situation of social and economic development has put forward many new requirements for college English teaching. Simple knowledgebased teaching is not only easy to cause the waste of college English teaching resources, but also dampens college students' initiative to learn English and the cultivation of English communication skills.

\section{B. There Is No Special Intercultural Awareness Training Courses}

At present, the teaching material adopted in college English teaching is mainly comprehensive public English course system. Although it can meet the teaching requirements of cultivating students' ability of speaking, listening, translating, reading and writing, there is no specific teaching material for the cultivation of intercultural awareness, which makes teachers' cultivation of students' intercultural awareness too scattered, not able to meet students' individual needs in English learning. This is not conducive to the systematic cultivation of students' intercultural communication ability. In addition, many college English teaching materials are generally less targeted. They haven't paid more attention to the cultivation of students' Chinese-English intercultural awareness, and adjusted themselves to students' individualized learning needs and the internationalization trend of English education and conducted systematic cultivation of students' Chinese-English intercultural awareness.

\section{The Means of Intercultural Awareness Cultivation Is Too Single}

On the whole, in the present stage of college English teaching, the cultivation of students' Chinese-English intercultural awareness has not yet formed a relatively perfect theoretical system. The cultivation of students' Chinese-English intercultural awareness is usually permeated in vocabulary teaching, oral teaching and listening teaching. So the teaching methods and cultivation strategies are also mainly about the traditional vocabulary teaching, listening and speaking teaching and reading teaching, which mainly focus on the one-way 
knowledge indoctrination of the teacher. It hasn't achieved diversification of education means. The students are not able to receive timely and intensive training inside and outside the classroom, and lack real understanding of Chinese-English cultural differences.

\section{Teaching Evaluation Mechanism Is Backward}

As one of the important links in college English teaching, teaching evaluation plays an important role in teaching information feedback, teaching methods adjustment and teaching quality improvement. ${ }^{[3]}$ It is also an essential link to assess the English quality of various talents in China. However, at present, most colleges and universities in China still follow the traditional assessment mode, which is based on end-ofsemester evaluation and CET 4 and CET 6. It hasn't set clear objectives and requirements for students' intercultural awareness and intercultural communication ability. This will not only have negative impact on the normal direction of college English teaching and result in the wrong guiding role, but also dilute the cultivation of students' English intercultural awareness and English communicative competence.

\section{EFFECTIVE MEASURES TO CULTIVATE STUDENTS' INTERCULTURAL AWARENESS IN COLLEGE ENGLISH TEACHING}

\section{A. Change the Concept of English Teaching and Pay More Attention to Intercultural Awareness Cultivation}

Based on the current situation that Chinese-English intercultural awareness cultivation is relatively backward in college English teaching, college English teachers need to actively change the teaching concept and traditional teaching mode, pay more attention to Chinese-English intercultural awareness cultivation, and make English culture teaching more interesting, so as to stimulate students' intrinsic motivation to communicate in English. In this regard, college English teachers need to change from teacher-oriented teaching to student-oriented teaching. They need to create more English teaching situations which students are familiar with, and conduct Chinese-English intercultural teaching in ways that students love, so as to improve the interestingness and interactivity of intercultural awareness teaching. They should maintain students' interest in English-Chinese intercultural learning and English communication, and avoid letting them lose interest in Chinese-English intercultural learning or even have psychological barriers. Let students have more successful and happy experience in English classroom, so as to continuously stimulate students' desire for English intercultural learning and communication.

\section{B. Enrich Intercultural Teaching Methods and Stimulate Students' Intercultural Communication Awareness}

In the information age, the methods of college English teaching and students' learning are becoming more and more abundant. Especially the application of network education and modern multimedia technology has widened and deepened the cultivation of Chinese-English intercultural awareness and improvement of students' intercultural communication ability. In this regard, college English teachers should make full use of the strong and rich network resources based on local college students' English learning needs and communicative needs, and stimulate students' communicative interest and enthusiasm through text, graphics, video, audio, animation and other educational carrier, letting the cultivation of Chinese-English intercultural awareness no longer be limited by time and place. According to students' English level and learning habits, help them choose their favorite learning style to actively carry out personalized learning and self-learning, so as to develop good English communication habits, accumulate the differences between Chinese and English culture, and effectively improve the efficiency of college English intercultural awareness cultivation. For example, normal lexical teaching is very boring. At this time, the teacher can penetrate cultural background knowledge in lexical teaching to train students' culture sensitivity, because many English words have accumulated rich cultural connotation during its long-term use, which is closely related to the living habits, folk customs, history and culture of western countries. For example, in the teaching of "dragon", it means auspiciousness, authority, wealth and good future in Chinese. But in Anglo-American culture, it refers to monster or ferocious person. ${ }^{[4]}$

\section{Develop the Second Classroom to Cultivate Students' Intercultural Awareness}

In the process of English learning, current students are not familiar with the cultural background of western countries because of their relatively small contact surface. This is a major factor that results in relatively weak Chinese-English intercultural awareness. Therefore, college English teachers should actively organize a variety of extra-curricular activities and develop the second classroom of intercultural education to develop students' intercultural awareness. For example, college English teachers should encourage and supervise students to take part in activities such as English Corner and Spoken English Skills Contest, listen to English radio and watch English movies, or organize lectures on Chinese and western culture or English learning methods, so that students can have more channels to learn about western countries' history, culture, customs and religious beliefs, excluding the negative influence of mother tongue on English communication. Effectively cultivate students' English communicative thinking, so that students can express their thoughts and feelings more easily.

\section{Improve the Overall Quality of English Teachers}

In order to further accelerate the connection of college English teaching with internationalization of education, and cultivate students' intercultural awareness and communicative competence in a better way, we must attach great importance to the construction of teaching staff which directly affects the teaching effect. ${ }^{[5]}$ Under the background of English teaching reform in higher education, the construction of teaching staff is the key to ensure the smooth implementation of college English teaching reform. Therefore, it is necessary to improve the professional level and quality of college English teachers, so as to improve the teaching level and quality and better meet China's realistic needs in English intercultural communicative talents cultivation. At present, it is an important part of the construction of teachers for college English teachers to participate in regular seminars or training. But this is far from 
enough for the cultivation of new English intercultural communication talents. On the basis of strengthening the training of teachers, colleges and universities need to encourage them to participate in domestic and foreign language teaching seminars and take the chance to study abroad, especially going to English-speaking countries. This can make them feel the "original" English culture and expand the intercultural education view of college English teachers, helping them gradually develop the correct thinking and concept of English intercultural awareness cultivation. In addition, on the basis of accumulating specialized knowledge of Chinese-English intercultural subject, college English teachers should also broaden their knowledge on culture, politics, economy, religion, agriculture, industry, architecture and geography of western countries, and accelerate the accumulation and integration of intercultural knowledge, so that they can obtain the quality and ability for Chinese-English intercultural awareness and communication ability cultivation as soon as possible.

\section{CONCLUSION}

In summary, at this stage of college English teaching, we not only need to develop students' basic ability to listen, speak, read, write and translate, but also need to focus on the cultivation of Chinese-English intercultural awareness. Because the ultimate goal of English learning is to improve students' ability to apply English knowledge and conduct intercultural communication, so that students can better understand the world and adapt to economic globalization trends. Therefore, college English teachers should pay more attention to the cultivation of students' Chinese-English intercultural awareness, and create good atmosphere and learning platform of English intercultural communication for students, comprehensively improving college students' Chinese-English intercultural communication awareness from all aspects.

\section{REFERENCES}

[1] He Ziying. College Students’ Intercultural Communicative Competence and Deep Intercultural Communication Barriers Analysis [J]. Science and Technology Information, 2011, (11).

[2] Wang Dongxia. Intercultural Language Teaching Situation Analysis and Countermeasure Research [J]. Journal of Dalian University, 2010, (04).

[3] Peng Shiyong. China's Intercultural Communication Research Situation and Predicament [J]. Journal of Shantou University (Humanities \& Social Sciences Edition), 2010, (04).

[4] Zheng Xiaohong. Ideas and Practice of Intercultural Talents Training with Chinese Characteristics - A Review of English Reading Course from Intercultural Perspective [J]. Foreign Language World, 2012, (02).

[5] Liu Jingxiu. Pragmatic Failure of College Students and Cross-cultural Teaching [J]. Journal of Jilin Institute of Education, 2011, (07). 